Professor Screech emphasizes the historical context of the first edition of the Pantagr line Prognostication and maintains, as he has done in his edition of Gargantua (TLF, 1971 that Rabelais' position is pedagogical, spreading "la leçon de son maître Erasme" (G., p. xxii), that Rabelais' political and religious views in the 1530 's correspond directly to thos of his patrons the Du Bellays and François I, and that "pour l'essentiel" there is nothing ambiguous about Rabelais' works (G., p. lxvii). There is clear evidence that Rabelais wrot the Pantagrueline Prognostication at least in part to reassure the French population, serio ly disturbed by almanacs violently favourable to Charles V's imperialist designs: "La nob royaulme de France prosperera et triumphera ceste année en tous plaisirs et délices, tellement que les nations estranges voulentiers se y retireront" (ch. vi). Rabelais also satirizes current credulity regarding specific predictions of "l'astrologie divinatrice" and argues in favour of an acceptance of and participation in the edicts of Divine Providence.

On the other hand, Professor Screech's careful conflations indicate that Rabelais' plan tary predictions correspond very closely to "scientific" accuracy, a fact which is borne ot by Rabelais' enduring reputation as a serious astrologer in an age when astrology was "an essential aspect of the intellectual framework in which men were educated" (Keith Thom Religion and the Decline of Magic [London, 1971], p. 285). Two of the extant almanacs by Rabelais (1541 and 1544) are not satirical; as Professor Screech points out, Rabelais well versed in the very acceptable astrological medicine. The editor might also have noted the high compliment paid by Pantagruel to Guillaume du Bellay, whose death, as befits th passing of a great man, was announced by comets (Quart livre, ch. xxvi-xxvii).

The title change of the Prognostication is not irrelevant; Rabelais warns that "Ceste année les aveugles ne verront que bien peu, les sourdz oyront assez mal ..." and that "M cure menasse quelque peu le persil ..." (ch. iii). It seems to me that there is as much play exploration of contradictions in accepted beliefs here as there is specific propaganda, and that Rabelais is exploring the possibilities of the "sign language" of astrology in much the same way as he explores other uses of language. The subject is worth further study, for w this volume is an essential primary source.

JANE COUCHMAN, Glendon College, York University

Etudes rabelaisiennes, t. XI (Travaux d'bumanisme et renaissance, CXXXIX). Geneva: Droz, 1974. Pp. xv, 147.

The question which occupies most space in this volume is that of the dating of Gargantua with M. A. Screech putting forward further points in support of his choice (pp. 9-56) and G. Defaux briefly summarizing his view (137-142). Marcel Françon supports Screech (81 82 ), and R. Maréchal devotes most of his preface to the debate. Unfortunately space doe not allow a review of all the arguments here. Screech's main point in favour of 1535 rath than 1534 is that Rabelais linked Tunis and Barbarossa, a connection unthinkable before the Turk captured the city, an event not generally known until the beginning of 1535 . T subsequently fell to Charles V in July of that year. Seeing Rabelais as an instrument of rc propaganda who assisted the Du Bellay brothers in their work, Screech finds that the aut belittled the Emperor's triumph by turning his victory into a comic episode of the Picroc 
line war. But Rabelais does not in fact link Barbarossa with Tunis. He mentions the Turk, and then three states on the Barbary coast, beginning with Tunis. As Maréchal points out, Barbarossa had gained a victory over Spain on that same coast in 1529; there was no need to wait until 1535 to make the mental association. Screech is more convincing when he deals with Defaux's point that "le Prince" of A is the printer Claude Nourry, by identifying him with his successor, Pierre de Sainte Lucie dict le Prince, who took over the printing works when he married Nourry's widow. The two critics agree that the fortunes of the Evangelicals varied as Francis I oscillated between persecution and tolerance, and that the Enigme must have been written after a period of the former. Defaux believes the "beaulx placards de merde" refer to those urging the recall of Béda from exile in May 1533 and that the reference was suppressed in B, after the October ' 34 Placards. He argues that the persecutions referred to in the Enigme are those at the end of 1533, during which Béda returned to Paris, while Screech argues that those persecutions belong to October ' 34 and January '35. M. Françon supports the latter, referring both to Francis I's two-faced policy, angling for the support of both the Pope and the Protestant German princes against the Emperor, and to the period of hope after the edict of Coucy of July 1535 as evidenced in some of Marot's Epîtres. Maréchal, on the other hand, feels that whereas Rabelais would be attacking the Sorbonne if he were referring to the May ' 33 placards, he would be criticizing the king if he were thinking of the more famous ones; he therefore prefers the earlier dating. As for the arguments over the language of A and B, Maréchal finds those of both sides inconclusive. To the non-specialist some of the arguments of both sides appear convincing, but neither side makes out a watertight case. One of the most persuasive for this reader is Screech's point that there is no evidence of any reaction to Gargantua until 1536 , in striking contrast to Pantagruel. This silence would be more understandable, as he remarks, if $A$ appeared in 1535 and B in late 1535 (o.s.), which could be up to Easter of 1536 (n.s.). Screech and Defaux make another contribution each to this volume, the former a note on Rabelais' Almanachs and Pantagrueline Prognostication to show that their astrological data were correct (pp. 1-17), the latter a stimulating article on "Rabelais et son masque comique" (pp. 89-135). He examines the character who has intrigued other critics, Alcofrybas Nasier, and finds a dual key in his sophistry and his resemblance to Panurge, his successor as lord of Salmiguondin. Both are sophists in their love of words and spinning of tales, their passion for minute detail and display of learning. They are arch-deceivers, creative artists. The one big difference between them is the Satanic side of Panurge. In Pantagruel Alcofrybas draws Panurge on, making him reveal the full depths of his infamy, thus rendering him harmless, a comic figure. With the absence of Panurge from Gargantua the role of Alcofrybas becomes correspondingly greater. As official historian to the house of Grandgousier it is his task to trace the genealogy of the young prince, to explain the colours of his livery and so on. Defaux argues that these aspects, the more archaic language of this second book, together with the use of Gothic characters in all the editions Rabelais supervised himself, point up the old-fashioned side of Alcofrybas and the fact that the author is parodying the old chroniclers. He takes issue with Screech and Saulnier for seeing Gargantua as a serious presentation of Rabelais' own ideas: Alcofrybas is not Rabelais but his somic mask. Moreover, the construction of the book is inspired by another aspect of the iophist's art: that of arguing pro et contra. Thus the education system of Ponocrates is irst and foremost the opposite of Thubal Holofernes' and is a satire of humanist education. 
Defaux agrees that it is easy to see where Rabelais' sympathies lie, but this is not to say th Alcofrybas is Rabelais, any more than one can confuse Folly with Erasmus; and the paral is clearly indicated by the subtitle of this article: Sopbista loquitur. This stress on the wo creative aspect seems somewhat to diminish certain of Defaux's arguments on the dating Gargantua. If Rabelais is primarily a creative artist it would seem that he would appreciat that the comic possibilities of the bells episode, for example, did not depend solely on its topicality-though it is no doubt less true of the satirist than of other writers that in his subconscious he stores up incidents to be reborn later in a different form. This poses in effect the question of how far Rabelais was a satirist and how far a purely comic writer.

This volume also contains articles by Rita Guerlac showing the close links between wh: Rabelais wrote on education and the De Disciplinis of Vives, published in Antwerp in 153 (pp. 63-72), and by A. P. Stabler on Thevet's accusation of plagiarism by Rabelais in his account of the Isle of Demons and the "paroles gelées." Since Thevet's version did not appear until after Rabelais' death the boot would, if anything, be on the other foot. In fact the source for both authors is a passage from G. Postel. There are also notes by $M$. Downes on the interpretation of arbre as mast, not rudder-bar (pp. 73-80), by D. Russell on the meaning of Panurge's "Pusse en l'Aureille" (pp. 183-88), by E. V. Telle on the origin of "Leur Robidilardicque Loy"-he has found the name of Martin Robillard in a list of lawyers-(pp. 143-44), and by P. Burrell on "aubelière," which, formed on aube (meaning "the anus") by analogy with muselière, signifies "an ass muzzle" (pp. 145-46).

\section{HELEN PURKIS, The University of British Columbia}

Margaret McGowan. Montaigne's Deceits, The Art of Persuasion in the Essais. Philadelphi: Temple University Press, 1974. Pp. viii, 207. \$9.

This is a most disconcerting book. Excellent in some of its parts, it is uneven in quality and unconvincing in structure. From a study of Montaigne's stylistic and rhetorical device in the Essais the author concludes that "There is a considerable distance between the spontaneity which Montaigne initially wants the reader to imagine as giving form to his ideas, and the studied naïvety which, in fact, he used." Of course, perceptive readers have long recognized that Montaigne's insistence on his amateur status as a writer and on his "natural" style should be taken with the proverbial grain of salt. A careful and systematic study of his "deceits" would therefore have been most welcome.

If this book is disappointing, it is chiefly owing to the fact that it simply does not hang together except, in a most superficial way, through the nature of the examples under stud It does not progress logically from the general to the particular, building a convincing thes as it goes. Instead, it begins with two chapters, "Montaigne's Modesty" and "Consciousnes of Style," which are little more than a collection of examples, and it is only in the third chapter, "Of the "Craftie and Secrete Methode," that the author relates Montaigne to the general rhetorical tradition of his period and begins to reveal the substance of her argumer To spread before the reader numerous examples of "studied naïvety" and to conclude froi other selected passages that Montaigne was falsely modest reveals nothing substantively ne about the essayist. 